\title{
Dose-response relationships of harlequin duck behaviour to noise from low-level military jet over-flights in central Labrador
}

\author{
R. IAN GOUDIE* AND IAN L. JONES \\ Atlantic Cooperative Wildlife Ecology Research Network, Department of Biology, Memorial University of Nemfoundland, St John's, NL, \\ Canada $A 1 B 3 X 9$
}

Date submitted: 23 January 2004 Date accepted: 29 September 2004

\section{SUMMARY}

Concern for the lack of field studies on the effects of low-level military jet over-flights on wildlife resulted in directed research in the Military Training Area of Labrador, 1999-2002. At Fig River, a tributary of the Lower Churchill River, a before-after-control-impact (BACI) study design quantified effects of aircraft overflights on behaviour of individual harlequin ducks (Histrionicus histrionicus) in the $130000 \mathrm{~km}^{2}$ Military Training Area of central Labrador. Noise generated from low-level passes (30-100 $\mathrm{m}$ above ground level) by military jets was sudden in onset and high in amplitude ( $>100 \mathrm{dBA})$, substantially above background sound levels both at Fig Lake outlet (40-50 dBA) and rapid sections of Fig River (60-70 dBA). Harlequin ducks reacted to noise from military jets with alert behaviour, showing a positive dose-response that especially intensified when noise exceeded $80 \mathrm{dBA}$. Residual effects, in other words, deviations from normal behaviour patterns after initial responses, were decreased courtship behaviour for up to $1.5 \mathrm{~h}$ after, and increased agonistic behaviour for up to $2 \mathrm{~h}$ after military jet over-flights. Direct behavioural responses to military jet over-flights were of short duration (generally $<1 \mathrm{~min}$ ), and were unlikely to affect critical behaviours such as feeding and resting in the overall time-activity budgets of breeding pairs. However, the presence of residual effects on behaviour implied whole-body stress responses that were potentially more serious; these require further study because they are potentially more detrimental than immediate responses, and may not be detected in studies that focus on readily observed overt responses. A dose-response curve relating particular behaviours of harlequin ducks to associated noise of over-flights could be a valuable conservation tool for the research and mitigation of environmental impacts of aircraft and other noise.

Keymords: before-after-control-impact, behavioural response, dose-response, jet aircraft noise, residual effects, time-activity budgets

\footnotetext{
* Correspondence: Dr R. Ian Goudie Tel: +1 7097378141 Fax: +1 7097373018 e-mail: igoudie@mun.ca
}

\section{INTRODUCTION}

Anthropogenic noise is defined as human-made sound that might significantly disturb animals (Bowles et al. 1991), and is thought often to be a biologically significant stressor on wildlife, yet knowledge of noise as a form of ecological disturbance is limited (Brown 2001a). The non-auditory effects of noise are classified as whole-body stress responses (Selye 1976). An animal's body can respond physiologically to noise while the animal is asleep, under anaesthesia, or even when the cerebral hemispheres are removed (Welch \& Welch 1970). When confronted with noise disturbance, an animal may choose a behavioural response, and/or evoke the autonomic and/or neuroendocrine systems. The responses of the last two systems result in changes in biological function, diverting the animal's own resources from ongoing biological activities to new biological activities that may assist the animal in coping with the stressor (Moberg 1987). Reflexes maybe weakened, learning responses lowered, and reproduction impaired through chronic exposure to harmful noise levels (Welch \& Welch 1970).

Ultimately, all responses to noise are affected by physiological changes in individual animals. Through behaviour, an animal may avoid disturbance or habituate if the stimulus is perceived as not harmful. Aircraft noise properties differ with aircraft type, and birds may respond differently to different aircraft types. Sudden-onset noise, typical of military jets, often elicits startle responses in wildlife that allow them to respond rapidly to possible dangers. The startle response is controlled and regulated by several neurophysiological processes (Bowles et al. 1991) that result in physiological changes (Hoffman \& Searle 1968). Animals habituate poorly to noise of high amplitude with rapid onset (Korn \& Moyer 1966).

Few studies have quantified dose-response effects of noise on wildlife, and advancement of knowledge in this field has been hampered by a preponderance of small, disconnected, anecdotal or correlational studies as opposed to the use of controlled experiments (Larkin 1996). Comparability among studies is complicated by wide variations in the definition of disturbance and variation in response among species (Ryals et al. 1999). Much of the existing literature adopts an 'all or none' view of impact (Trimper et al. 1998), or has used surrogate information, such as distance of study animals to disturbance source (Grubb \& Bowerman 1997), to evaluate noise events in the field (Brown 2001a). 
Quantifications of the acoustic background in natural environments are crucial to understanding effects of noise on wildlife because they provide a baseline against which levels of intruding noise can be assessed (Brown 2001a). Causal association can most convincingly be established by demonstrating an increase in an adverse outcome (response) with corresponding increases in the level of exposure (dose) (Bowles et al. 1991), and dose-response is the preferred approach to mitigating negative impacts of noise on humans (Fidell et al. 1991). Our field studies aimed to experimentally quantify the dose-response relationship between military jet noise and avian behaviour.

Harlequin ducks (Histrionicus histrionicus) are small sea ducks that inhabit fast-moving rivers and streams during the breeding season (Robertson \& Goudie 1999), and their populations are sensitive to relatively small changes in adult survival (Goudie et al. 1994). The eastern North American population of harlequin ducks that breed throughout central Labrador was listed as endangered in 1990, and down-listed to species of concern in 2001 (Committee On the Status of Endangered Wildlife In Canada, Report 1990, 2001).

The Canadian Department of National Defence (DND) supports a low-level training programme involving military jets in a Military Training Area (MTA) encompassing about $130000 \mathrm{~km}^{2}$ of central and southern Labrador. Following an environmental impact statement (EIS), management actions by DND are to be adjusted based on scientific research. Military jets frequently follow river valleys during low-level sorties $\left(30-150 \mathrm{~m}\right.$ above ground level) at speeds of $780-890 \mathrm{~km} \mathrm{~h}^{-1}$, generating loud noise exceeding $100 \mathrm{dBA}$ (DND 1994).

Our study addressed the following questions: (1) did military jet noise exceed the background sound levels at riparian sites; (2) did harlequin ducks respond to low flying military jets; (3) what was the relationship between behavioural response and the intensity of noise levels; and (4) what are the conservation implications of low-flying military jets to harlequin ducks breeding in the MTA?

\section{METHODS}

\section{General behaviour}

Commencing in 1999, we initiated research on the effects of military jet noise on behaviour and demography of harlequin ducks breeding at Fig River $\left(53^{\circ} 03^{\prime} \mathrm{N}, 63^{\circ} 09^{\prime} \mathrm{W}\right)$ near the geographic centre of the MTA, and at Crooked River (54 $06^{\prime} \mathrm{N}, 60^{\circ} 48^{\prime} \mathrm{W}$ ) near Nipisish Lake, a control site just outside the MTA. We quantified behaviour of breeding pairs of harlequin ducks during mid-May to mid-June of 2001 and 2002. A focal-individual sampling approach (Altmann 1974) was applied, and linked to known individuals because most Harlequin ducks at Fig River (treatment site, $n=95$ ) and Crooked River (control site, $n=45$ ) were individually marked with field-readable coloured plastic leg bands from 1999 to 2002.
Table 1 General categories used to summarize behaviours of harlequin ducks. Behaviours were segregated into those on the water and those out of the water to give a total of 16 categories of behaviour.

\begin{tabular}{lc}
\hline Behaviour & Description \\
\hline Agonism & $\begin{array}{c}\text { Aggressive interactions among harlequin ducks } \\
\text { including chasing and sometimes fighting with } \\
\text { conspecifics }\end{array}$ \\
Courtship & All courtship behaviour (on the water), for \\
& example inciting, prone, copulation \\
Feed & All aspects of obtaining food, including dip, dive, \\
& submerged, pause or glean \\
Peer & Looking into water (maybe associated with food \\
& seeking) \\
Locomotion & All types of movements, for example swim, scoot, \\
& fly or walk \\
Preen & Feather maintenance using the bill as well as \\
& flapping and shaking \\
Rest & Inactivity including sleeping and head down \\
Social & Directed calls and head nods \\
Vigilant & Maintaining a look-out (vigil), usually while the \\
& mate feeds or sleeps \\
Alert & Head stretched upward, body erect/tense, \\
& re-orientation, and agitated, often \\
& accompanied with locomotion. Includes \\
& startle responses such as splash dive and panic \\
& flush.
\end{tabular}

Behaviour of harlequin ducks was characterized during bouts or states (for example feeding and resting). For standardized watches, focal birds were monitored for $30 \mathrm{~min}$ (or until lost from sight) using binoculars and/or $(20 \times-60 \times)$ spotting scopes. Instantaneous behavioural classifications of focal birds were recorded every $15 \mathrm{~s}$, using digital watches with countdown-return beeper functions, from a suite of 16 general behavioural categories (Table 1). For analyses it was necessary to group individual behaviours because the entire database contained approximately 220 unique behaviours. For example, feeding consisted of diving, pausing, dipping and gleaning that were further subdivided into other behaviours, including pause-swim, pause-paddle and pausepeer. We designated agonistic, alert and vigilance as having precedent over other behaviours, notably feeding, resting and locomotion.

To minimize the chance that individuals were observed more than once, and to maximize the independence of our data, a new individually colour-marked bird was selected for observation, or observers changed location to find new birds, after each 30-min observation period was completed. Our data were not pseudo-replicated. Since instantaneous data recorded every $15 \mathrm{~s}$ were not statistically independent within each 30-min watch, frequencies of behavioural categories were summed over each watch; each behavioural watch contributed one data record as the frequencies of the individual behaviours recorded in the 120 instantaneous records of a standard $30 \mathrm{~min}$ watch. 


\section{Undisturbed versus disturbed categories}

Observation periods were classed as 'disturbed' or 'undisturbed', 'disturbed' being the case where focal birds were over-flown by a military jet at Fig River within the first 20 min of a 30-min observation period. Concurrent data were collected at the control site at Crooked River, where no overflights occurred; the forecast timings were communicated between field crews via satellite telephones as expected time on target (TOT, see below). For the before-after-controlimpact (BACI) study design (see section on statistical design later) there were data collected on paired harlequin ducks as 'before treatment' in 2001 and 'after treatment' in 2002 at Fig River (females: $n=30$ and $n=42$, males: $n=30$ and $n=45$ ) and Crooked River (females: $n=32$ and $n=28$, males: $n=32$ and $n=30$ ), respectively, and the 'after treatment' corresponded to behavioural watches when over-flights by military jets occurred in 2002. Therefore, there were differences between achieved sample sizes for the 'after' components at the treatment (Fig River) and Control (Crooked River) sites attributable to inherent problems of coordinated observations at two isolated and remote field sites, in other words, there were fewer samples for the control site during the 'after' component.

Residual effects were defined as ongoing deviations from normal behaviour patterns that followed the initial response and persisted well after the passage of an aircraft. These were assessed at Fig River within the 2002 treatment year subsequent to detecting an overall effect using the BACI study design. The standardized behavioural observations at Fig River were classed as: during, $<30 \mathrm{~min}, 30-60 \mathrm{~min}, 60-$ $90 \mathrm{~min}$ and $90-120 \mathrm{~min}$ periods before and after military jet over-flights in order to assess potential residual effects on behaviour.

\section{Military jet over-flights}

We scheduled some observation periods to coincide with expected times of military jets transits over the study area. In 2002, mock tank targets were airlifted and placed on peatlands within $300 \mathrm{~m}$ of the outlet of Fig Lake, and used for the tactical training of pilots. Staff at 5-Wing Goose Bay airport relayed TOT of military jet over-flights to our field observers via satellite phone following the submission of daily flight plans by allied pilots. Over-flights at Fig River related predictably to take-off times from the airfield at Goose Bay, so regular contact with Military Command Centre (MCC) staff by satellite phone resulted in accurate forecasting of military jet over-flights. Simultaneous data collection was achieved at Crooked River (control site) in 2001 and 2002.

The time of each aircraft transit over the study area and aircraft type were recorded whenever possible. When the overflying aircraft was visible, we noted the cardinal direction of transit, estimated altitude and whether the aircraft transited over the Fig Lake outlet location where a digital time-logging Larson Davis Model 820 Sound Level Meter was deployed (see below). Our field crew relayed time of transiting of the study site by military jets to 5 Wing Goose Bay airport on a daily basis.

\section{Sound and noise data}

Sound meters were deployed within $2 \mathrm{~m}$ of the river edge in areas frequented by the harlequin ducks under observation. A continuous digital time-logging Larson Davis Model 820 Sound Level Meter (LD820) (Larson Davis Laboratories 1997) was programmed and deployed at the outlet of Fig Lake in the area of maximal use by pairs of harlequin ducks. Collected sound data were A-weighted because this scale approximates the hearing sensitivity of most birds, and is the standard scale generally used to quantify aircraft noise in avian studies (Brown 1990). Birds approach the levels of sensitivity for simple sounds of humans, and thresholds for the detection of changes in intensity, frequency and temporal aspects of a simple signal approximate those for humans. Extreme caution should be observed in interpreting the differences between Strigiformes and other groups of birds, as owls have unique hearing abilities (Dooling 2000).

For the analyses of dose-response we used the sound measure $L_{\text {max }}$ recorded every $60 \mathrm{~s}$ and as mean values every 30 min. $\mathrm{L}_{\max }$ was the maximum sound pressure level (as Aweighted decibels) measured over the sampled period (in this case the jet over-flight event). To approximate the background level of sound on the study area, the metric $\mathrm{L}_{90}$ was chosen; it represented the sound level exceeded $90 \%$ of the time (N. Stanton, personal communication 2000). Additionally, we compared $\mathrm{L}_{\text {max }}$ of military jet over-flights with background levels at Fig Lake outlet and along sections of rapids and riffles further downstream. In addition to military jets, 'loud noise' events also included project-related aircraft and phenomena such as thunder or heavy rain.

We used the 'Passby' function, a special exceedance event detector of the LD820 Sound Level Meter that measured the $\mathrm{L}_{\max }$ of the highest event to raise and lower $\geq 10 \mathrm{~dB}$ in Sound Pressure Level. It was used to capture single event noises (Larson Davis Laboratories 1997), and is preferred for measuring transient noise events (Pater 2001). $\mathrm{L}_{\max }$ was modelled against the behavioural response variables of the harlequin ducks in an effort to assess evidence for a doseresponse relationship.

Data were logged daily from $0500 \mathrm{~h}$ to $2100 \mathrm{~h}$ local time to coincide with activity by harlequin ducks at the outlet of Fig Lake and to encompass over-flights by military aircraft. Behavioural data were also collected at other sites along Fig River and Fig Lake, and we recorded sound during those 30-min watches using hand-held digital Larson Davis Model DSP80 Sound Level Meters (Larson Davis Laboratories 1997). These recorded A-weighted $\mathrm{L}_{\max }$ in decibels integrated over the 30 -min observation period.

In addition to the noise levels measured, the date and time of $\mathrm{L}_{\max }$ and the duration of each event were recorded. The recorded maximum duration of the 'passby' event was $64 \mathrm{~s}$ or $128 \mathrm{~s}$, depending on whether a $0.5 \mathrm{~s}$ or $1.0 \mathrm{~s}$ time-history 
Table 2 Date and time of over-flights by military jets with some concurrent sound metrics (mean \pm SD) at Fig Lake outlet and rapids. $-=$ no data.

\begin{tabular}{|c|c|c|c|c|c|c|}
\hline \multirow[t]{2}{*}{$\overline{\text { Date }}$} & \multicolumn{3}{|c|}{ Number of flights during time period } & \multicolumn{3}{|c|}{$\bar{L} L_{\max }$} \\
\hline & $0900-1300$ & $1300-1700$ & $1700-2200$ & Fig Lake & Rapids & Military jet \\
\hline 22 May 2002 & - & 1 & - & - & - & - \\
\hline 25 May 2002 & - & 6 & - & - & - & - \\
\hline 27 May 2002 & - & - & 2 & - & - & - \\
\hline 28 May 2002 & - & 9 & 2 & - & - & - \\
\hline 29 May 2002 & - & 3 & - & $53.1 \pm 2.81$ & $66.7 \pm 7.1$ & $109.9 \pm 0(n=2)$ \\
\hline 30 May 2002 & - & - & - & $55.3 \pm 6.18$ & $67.8 \pm 0.78$ & $115.5 \pm 0(n=2)$ \\
\hline 3 Jun 2002 & 5 & - & - & 54.8 & 66.1 & 94.1 \\
\hline 4 Jun 2002 & 4 & - & - & $58.1 \pm 1.34$ & $67.1 \pm 0.57$ & $102.2 \pm 2.83(n=2)$ \\
\hline 5 Jun 2002 & 2 & - & - & 56.3 & 68.0 & 111.1 \\
\hline 7 Jun 2002 & - & 4 & 2 & - & - & - \\
\hline 8 Jun 2002 & 4 & - & 1 & $52.5 \pm 1.50$ & $68.1 \pm 1.33$ & $94.2 \pm 8.04(n=3)$ \\
\hline 10 Jun 2002 & 3 & - & 2 & - & - & - \\
\hline 11 Jun 2002 & 17 & - & - & $55.8 \pm 1.08$ & $67.1 \pm 1.24$ & $104.4 \pm 8.29(n=5)$ \\
\hline 13 Jun 2002 & - & - & 1 & - & - & - \\
\hline 15 Jun 2002 & - & 1 & - & 57.1 & 67.3 & 82.0 \\
\hline 18 Jun 2002 & 9 & 8 & - & $57.2 \pm 1.80$ & $68.2 \pm 1.80$ & $101.8 \pm 8.32(n=5)$ \\
\hline
\end{tabular}

period was selected on the LD820 meter. Ten samples before and after the exceedance were stored, up to a maximum of 255 samples, with each sample period being $1 / 32 \mathrm{~s}$; equivalent to $8 \mathrm{~s}$ before and after the over-flight event in our study. For the Fig River study, we set the time-history period of exceedances to $0.5 \mathrm{~s}$ that were logged for events with a minimum duration of $3 \mathrm{~s}$ and exceedance threshold of $75 \mathrm{dBA}$.

\section{Experimental and statistical design}

Our study design applied a BACI statistical approach (Green 1979), controlled in both space and time. The general linear model for BACI is a two-way ANOVA with an area by time $2 \times 2$ factorial design, where the evidence for impact effects is a significant interaction term (Green 1979).

The behavioural data collected every $15 \mathrm{~s}$ during a $30-\mathrm{min}$ watch were binomial in nature; the birds either responded with a given behaviour or they did not. Therefore response was modelled using a binomial distribution with a logit link in the GENMOD procedure of SAS (SAS Institute Inc. 1993). We used a case-control study that modelled the data as the odds ratio, a method of association frequently used to assess the relative risk of rare diseases (Agresti 1996). In this study, the odds ratio was the ratio of the probability of the behaviour occurring given exposure to a military jet overflight to the probability of the behaviour occurring with no over-flight. Odds were defined as $p / q$, where $p=$ the relative frequency of a given behaviour and $q=1-p$ or the relative frequency of not being in a given behaviour. Odds may be stated as the probability of engaging in a behaviour relative to the probability of not engaging in that behaviour (after Zar 1999). The data were presented as proportions for more direct interpretation.
We assessed the evidence for a dose-response relationship using the odds of a behaviour occurring (binomial response) in relation to noise dose received. Test statistics were a $X^{2}$ distribution with $\alpha=0.05$. An approximation of the explanatory power of the relationship was given by the deviance ratio:

$$
\frac{\text { Deviance of intercept }- \text { Deviance of } \mathrm{L}_{\max }}{\text { Deviance of intercept }}
$$

after Agresti (1996).

This is analogous to a coefficient of determination $\left(R^{2}\right)$ in standard linear regression, that is, the expression of the proportion of the total variability in the $Y$ (response) attributable to the dependence of the response on $X$ (noise dose) (Zar 1999).

\section{RESULTS}

From 6 May-15 June 2001, there were only four military jet over-flights events registered at the Fig Lake study area, and therefore this time period was treated as the before component of the BACI design for the treatment site. The after component data were obtained 19 May-18 June 2002, when military jets made 92 low-level over-flights of the Fig River study site. Approximately $66 \%$ of over-flights occurred in early- to mid-June and 33\% occurred on two days. A total of 47 over-flights occurred during $1000-1300 \mathrm{~h}$ and 32 were in the $1500-1700 \mathrm{~h}$ period (Table 2).

\section{Background sound and jet noise}

Noise generated by military jets was much higher than background sound levels near the outlet of Fig Lake (40-50 dBA) 




Paired males

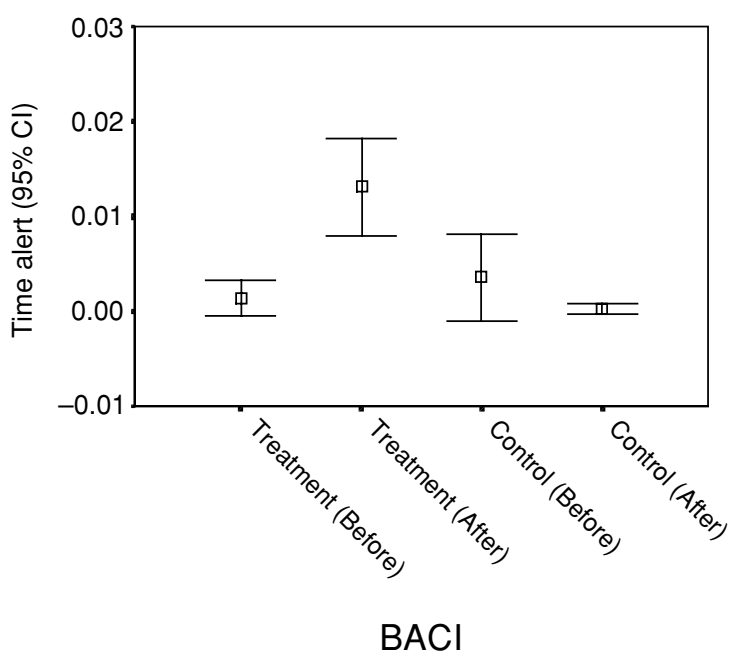

Figure 1 Proportion of time (mean $\pm 95 \% \mathrm{CI}$ ) spent being alert of paired female and male harlequin ducks in treatment and control locations before (2001) and after (2002) military jet over-flights.

and along the rapids and riffles of Fig River (60-70 dBA) (Table 2). Noise events related to military jet over-flights were sudden in onset and were high in amplitude (mean $\mathrm{L}_{\text {max }}$ : $91.4 \mathrm{dBA} \pm 11.7 \mathrm{SD}$, mean peak: $101.9 \mathrm{dBA} \pm 13.3 \mathrm{SD}$ ), but were brief $($ mean $=6.1 \mathrm{~s} \pm 3.7 \mathrm{SD}$ raised $10 \mathrm{~dB}$ above background sound level). The A-weighted maximum peak noise level registered during an over-flight by a military jet was $129.3 \mathrm{dBA}$.

\section{Effects on behaviour}

Harlequin ducks increased alert behaviour during military jet over-flights, including head-up orientation, and general agitation and startle responses such as flushing and panic diving related to this sudden-onset noise (females: time $\times$ treatment: $\chi^{2}=38.79, p<0.0001$; males: time $\times$ treatment: $\chi^{2}=31.21, p<0.0001 ;$ Fig. 1$)$.

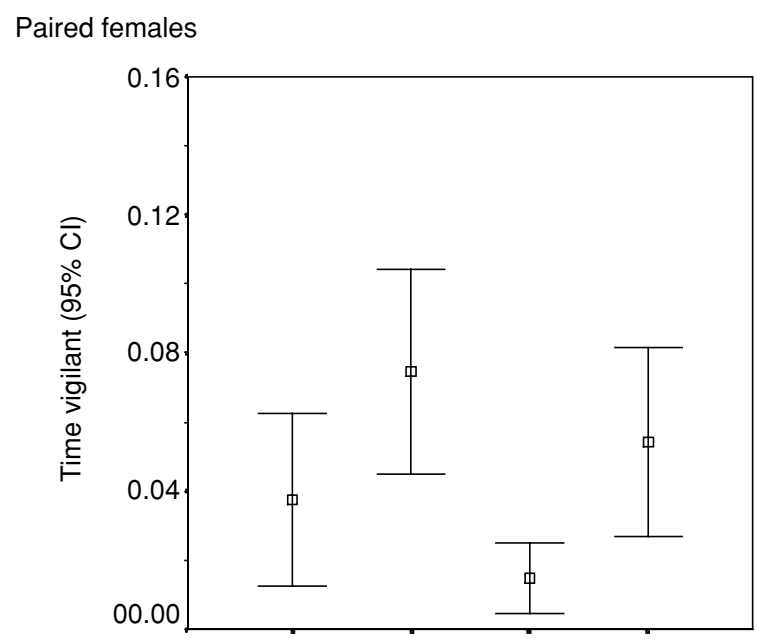

Paired males

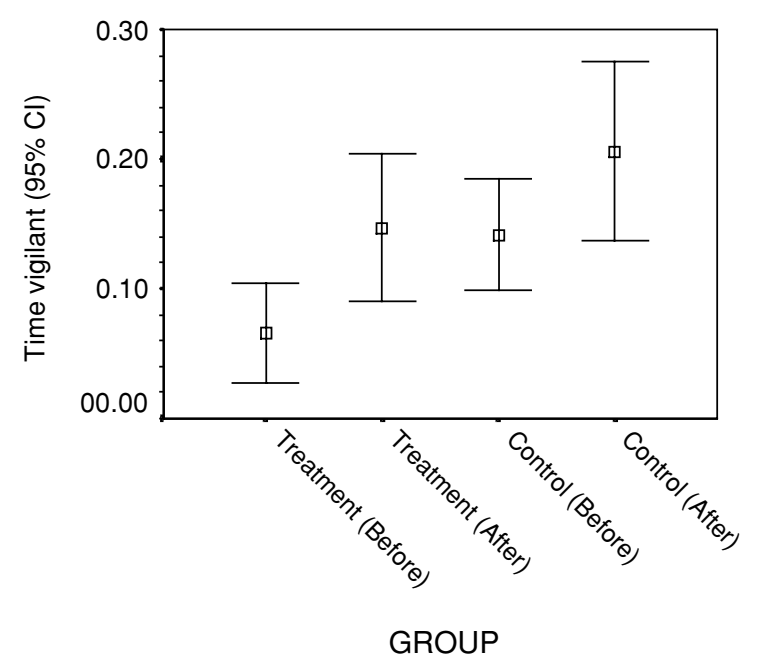

Figure 2 Proportion of time (mean $\pm 95 \% \mathrm{CI}$ ) spent being vigilant of paired female and male harlequin ducks in treatment and control locations before (2001) and after (2002) military jet over-flights.

Results of the BACI model for other behaviour categories were interpreted less readily; for example there was a significant interaction term for vigilant behaviour (females: $\chi^{2}=5.08, p=0.024$; males: $\chi^{2}=26.14, p<0.0001$; Fig. 2 ) suggesting that harlequin ducks increased vigilance during over-flights by military jets. However the source of the significant time $\times$ treatment interaction was not compelling because the proportion of time being vigilant increased during the treatment year (2002) at both sites, but not significantly for females, whereas paired males displayed significantly more vigilance at the treatment site following military jet overflights, but not at the control site.

\section{Dose-response relationships}

Alert behaviour increased with increasing dose of military jet noise, there were highly significant dose-response 


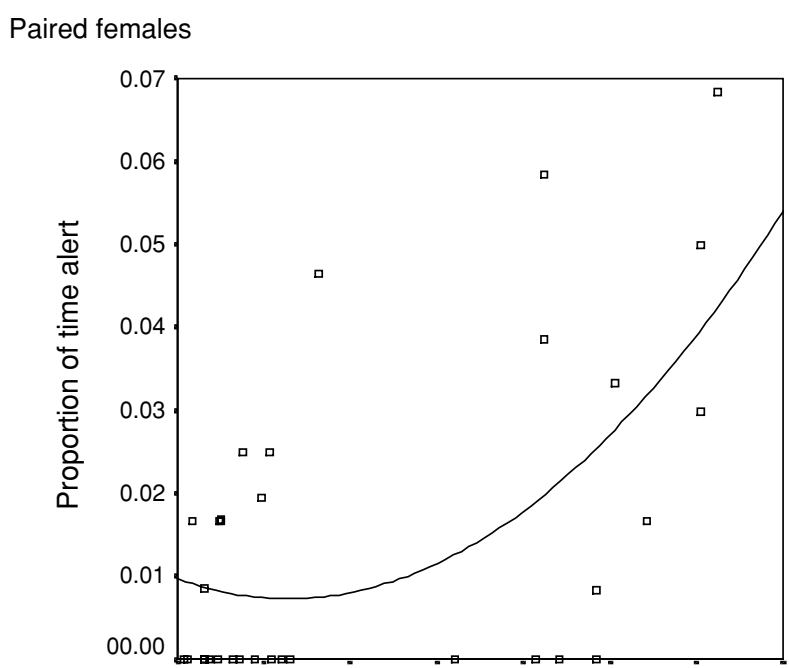

Paired males

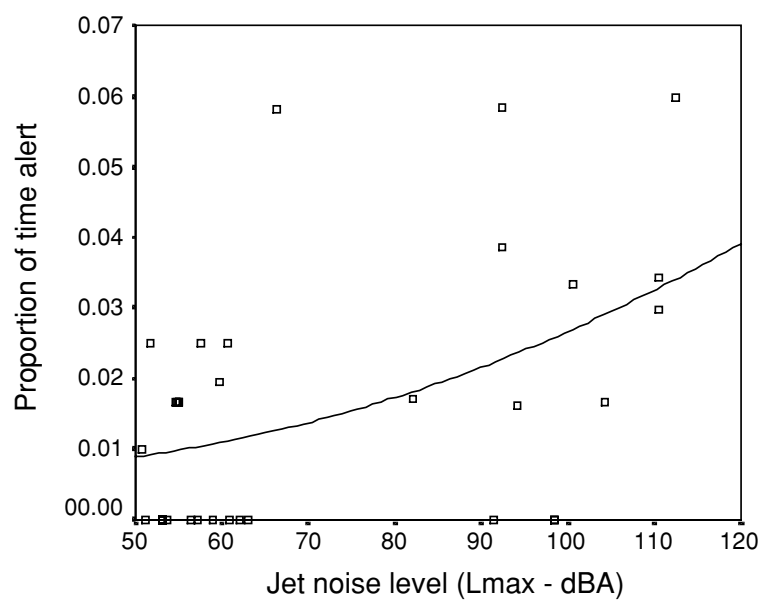

Figure 3 Proportion of time alert (mean $\pm 95 \%$ CI) versus noise level ( $\mathrm{L}_{\max }$ in A-weighted decibel) of paired female (odds of alert = $\mathrm{e}^{\left[-6.437 \pm 0.549+0.0287 \pm 0.0062 \mathrm{~L}_{\max }\right]}+\in$ ) and male harlequin ducks (odds of alert $\left.=\mathrm{e}^{\left[-5.775 \pm 0.503+0.0215 \pm 0.0059 \mathrm{~L}_{\max }\right]}+\epsilon\right)$ at Fig River, central Labrador, 19 May- 8 June 2002.

relationships for the odds of being alert to noise levels generated by military jets (females, slope $(\beta i): \chi^{2}=21.42$, $p<0.0001$; males, slope $\left.(\beta i): \chi^{2}=13.25, p=0.0003\right)$ and the relationship was stronger for paired females than paired males (deviance ratio of females $25.1 \%$, males $16.7 \%$; Fig. 3).

\section{Residual effects}

There was evidence of residual effects of noise generated by military jet on behaviours, agonism (paired females $\chi^{2}=$ 67.27, $p<0.0001$; paired males $\chi^{2}=50.77, p<0.0001$; Fig. 4) and courtship (paired females: $\chi^{2}=60.09, p<0.0001$; paired males $\chi^{2}=57.05, p<0.0001$; Fig. 5). The frequency of agonistic behaviour was higher for up to $2 \mathrm{~h}$ following overflights, and the frequency of courtship behaviour was reduced for up to $1.5 \mathrm{~h}$ following over-flights compared with levels of

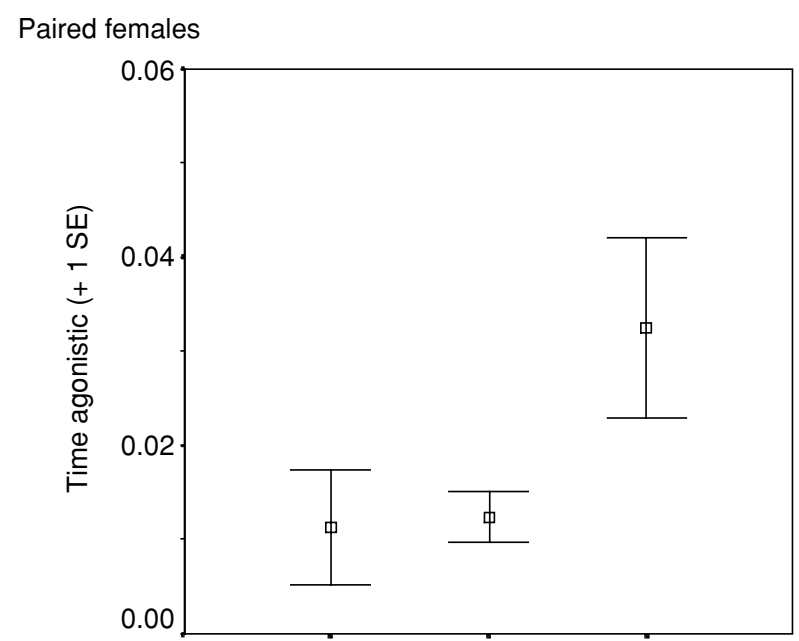

\section{Paired males}

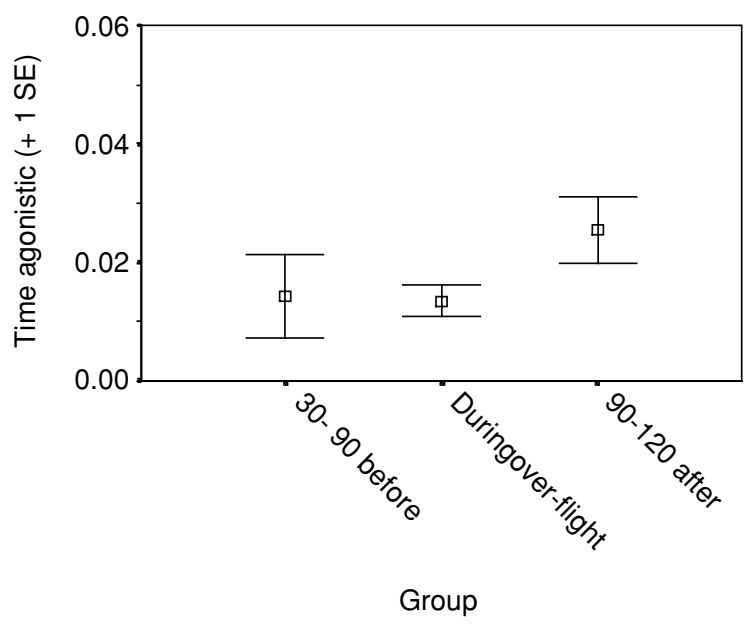

Figure 4 Proportion of time agonistic (mean $\pm 1 \mathrm{SE}$ ) of paired female and male harlequin ducks before $(n=28)$, during $(n=45)$ and after over-flights $(n=50)$ by military jets at Fig River, central Labrador.

these behaviours exhibited prior to over-flights. We did not detect differences in other behaviours before, during and after over-flights.

\section{DISCUSSION}

Our research highlights the need for serious consideration of the potential environmental impacts of aircraft noise, and has broad application in an international context because few past studies have quantified noise levels concurrent with response variables. Alert responses of harlequin ducks especially intensified when noise levels exceeded about $80 \mathrm{dBA}$; this concurs well with other avian studies (for example Thiessen et al. 1957; Brown 1990) and is an important conservation tool in designing impact research and mitigation (Burger 1981; Pater 2001). Failure to consider noise response thresholds could lead to erroneous conclusions; for example, 
Paired females

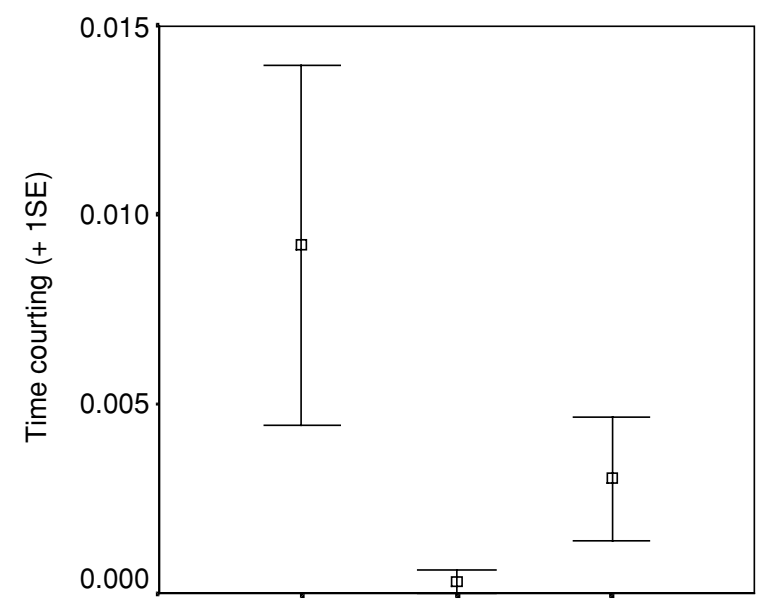

Paired males

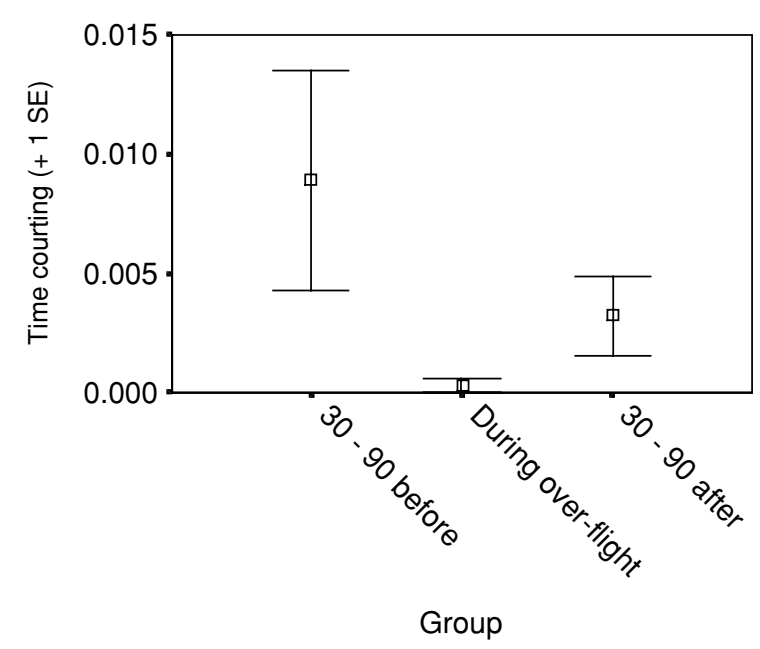

Figure 5 Proportion of time (mean $\pm 1 \mathrm{SE}$ ) spent in courtship of paired female and male harlequin ducks before $(n=28)$, during $(n=45)$ and after over-flights $(n=44)$ by military jets at Fig River, central Labrador.

Trimper et al. (1998) reported jet activity had no effect on osprey in the MTA of Labrador possibly because many noise treatments were below $80 \mathrm{dBA}(<50 \%$ exceeded $80 \mathrm{dBA}$, $<5 \%$ exceeded $90 \mathrm{dBA}$ ) and only $32 \%$ of 72 over-flights were within $1 \mathrm{~km}$ of five treatment nest sites under study. Harrington \& Veitch (1991) noted that the greatest impact of low-level flying jet aircraft on caribou in Labrador was because of startle reactions induced by the loud and sudden noise of low, direct over-flights. Beyond $250 \mathrm{~m}$ from the jet's flight path, the mean sound pressure level for jet overpasses was $<90 \mathrm{~dB}$, which was less aversive.

Effects of military aircraft noise on wildlife have been reported for other species such as increasing flushing frequency in Mexican spotted owls Strix occidentalis lucida with increasing noise level from helicopters (Delaney et al. 1999). In general, it is known that birds respond to aircraft noise (Burger 1981; Trimper et al. 1998; Hunsaker 2001; Murphy et al. 2001), as do caribou Rangifer tarandus (Harrington \& Veitch 1991; Jung \& Jones 2001; Maier et al. 2001). Some previous studies have inferred dose-response behaviour in relation to distance from disturbance stimuli as a surrogate to noise level (Anderson 1988; Grubb \& Bowerman 1997). Nevertheless, the effects of noise on wildlife cannot be generalized across taxa, and some waterfowl species may habituate to jet noise (for example black ducks Anas rubripes), whereas others may become sensitive (for example wood ducks Aix sponsa) (Fleming et al. 1996).

We concur with Brown (2001b) and Ward et al. (2001) that noise was likely to be the main stressor involved behavioural responses to aircraft over-flights. Harrington and Veitch (1991) noted that noise was the primary stressor in military jet over-flights in Labrador because, as at Fig River, their study area supported a mature black spruce (Picea mariana)-balsam fir (Abies balsamea) forest averaging $10-15 \mathrm{~m}$ in height. Normally the jets had already invisibly passed before their presence was detected by the delayed sound wave in their wake (sometimes seen briefly as they recede in direct over-flights). Nevertheless, we were unable to absolutely isolate optical and/or vibrational stimuli from acoustic stimuli.

In the context of time-activity budgets, alert behaviours contributed a small fraction of the daily activity in undisturbed $(\sim 0.1 \%)$ and disturbed $(\sim 1.0 \%)$ scenarios. It appeared unlikely that direct (alert) responses to military jets could jeopardize the ability of adult harlequin ducks to budget sufficient time to feeding unless the frequency of over-flights was considerably greater than the 94 registered in our study. Currently there is ample flexibility in the time-activity budget for compensatory adjustments for important behaviours, and harlequin ducks and other sea ducks can spend much higher proportions of the day feeding if necessary (Goudie $\&$ Ankney 1986). Some species of birds can also increase the intensity of feeding (Swennen et al. 1989). We were cautious about our interpretation of the supported effect of military jet noise on vigilant behaviour in paired male harlequin ducks. We noted that vigilance is a behaviour exhibited primarily by paired males, contributing towards maintenance of pair bond and ensuring parental investment (Squires 2003). This may explain the lack of compelling evidence for an effect on paired females.

Because increased agonistic behaviour and decreased courtship could last for more than hour following overflights by military jets, the effects on time-activity budgets of adult harlequin ducks are potentially more serious than the demonstrated short-term immediate alert responses. If behaviour changes follow over-flights, then some interference with feeding and resting could result. Increased aggression has been noted in some birds subjected to aircraft disturbance and could have negative consequences for the stability of pair bonds or the site fidelity of the harlequin duck because birds may avoid sites of repeated over-flights (Bowles et al. 1991). Increased aggression could also reduce time allocated 
to courtship. Reduced courtship following over-flights by military jets could affect the stability of strong pair bonds and reduce fertility of eggs, which are laid every other day until the clutch is complete (an approximately two-week period; Robertson \& Goudie 1999). Fertility in poultry was impaired by noise-related stress (Kosin 1958).

There is a close correspondence between behavioural responses and physiological measures (Thiessen \& Shaw 1957; Bowles et al. 1991). Noise generated during over-flights by military jets in Labrador increased heart rates in black ducks (Trimper et al. 2003), and mice (Mus musculus) collected from fields subjected to 80 to $120 \mathrm{~dB}$ from low-flying aircraft displayed larger adrenal glands than mice collected from control fields (Chesser et al. 1976). Alert and aggressive behaviours correlate with stress because they are aspects of the 'fight or flight' response that occurs with the activation of the neurophysiological system. Chronic stress can lead to loss of immune function, decrease in body weight, depression, impaired reproductive function and abnormal thyroid function (Seyle 1976). Linkages between indices of stress, such as heart rate and circulating levels of cortisol, are more presumptive than real, but prolonged exposure to high noise levels may have physiological consequences and startle responses have more serious (immediate) consequences (Bowles et al. 1991).

Harlequin ducks living in an environment with relatively loud background sound levels may ironically be at increased risk from the effects of additional anthropogenic noise; some species may become more sensitive to noise stressors, which they were otherwise habituated to under lower-ambient background levels (Davis 1974).

The frequency of over-flights by military jets at the Fig River study area in 2002 was considerably higher than that experienced on average across the MTA (Pigeon 2001). Military jets often selectively use river valleys in Labrador, and in watersheds such as the Nauskapi-Red Wine Rivers $\left(54^{\circ} \mathrm{N}\right.$ $61^{\circ} \mathrm{W}$ ) a high frequency of over-flights may coincide with concentrations of harlequin ducks because of the heavy use of these valleys for sorties to and from the northern portions of the MTA.

There are few published scientific studies on the effects of aircraft noise on the environment, yet this anthropogenic stressor is of international scope. Our study supported that important effects may easily be overlooked because researchers often a priori define 'behavioural responses' that are easily observed, yet effects may be subtle and protracted. Nevertheless, we lack an understanding of how proximate behavioural effects translate into demographic consequences for wildlife (see Brown 2001a). Based on our findings, we recommend a precautionary approach to mitigation and, in Labrador, military aircraft over-flights should be modified to reduce the exposure of river habitats used by harlequin ducks to aircraft noise levels $>80 \mathrm{dBA}$. This could, for example, involve avoiding river valleys or defining minimum altitudes for over-flights that assure noise levels remain below this threshold, or is less sudden in onset.

\section{CONCLUSIONS}

Noise generated from low-level military jet over-flights was high in amplitude and substantially above the ambient sound environment of the riparian habitat of the eastern harlequin duck in central Labrador. Individual birds responded to the sudden onset noise by exhibiting alert behaviours, and these increased with increasing amplitude. Short-term effects on time-activity budgets were negligible because alert behaviour constituted $<1 \%$ of the diurnal period. We noted increased agonistic behaviour up to $120 \mathrm{~min}$ after over-flights and decreased courtship behaviour up to 90 min after over-flights; this indicates the physiological response of the harlequin duck to military jet noise was greater than previously assumed. Such residual effects are cause for concern, because they are potentially more detrimental than immediate responses and may not be detected in studies that focus on readily observed overt behaviours. The alert and aggressive responses we documented are indicative of 'fight or flight' responses, and imply that harlequin ducks perceived loud military jet noise as a stressor. Chronic exposure to military jet noise could have negative consequences for individuals. We identified a threshold of response to noise approximating $80 \mathrm{dBA}$, and therefore future research should quantify noise levels concurrent with responses. Future mitigation could include appropriate altitudinal and horizontal buffer zones for riparian habitats used by harlequin ducks in order to maintain noise below this level and/or reduce the potential for sudden-onset military jet noise.

\section{ACKNOWLEDGEMENTS}

Many people contributed to the success of this research project and we acknowledge the following contributions. For field assistance we thank Simon Andrew, Tina Andrew, Joachim Andrew, Simon Andrew Jr, Penote Andrew, Christine Andrew, Teresa Andrew (elder), Teresa Andrew, Ben Andrew, Jeremy Andrew, Michel Andrew, Guy Andrew, Eric Andrew, Valerie Busque, Mark Dalton, Alain Fontaine, Steve Gale, Trevor Hann, Kathy Hogan, Colin Jones, Tom Jung, Bruce MacTavish, Dr Margaret McKenna, Shannon McLaughlin, Tina Newbury, Rich Neville, Keith Oram, Tony Parr, Frank Phillips, Kirk Pilgrim, Bobbie Randell, Amber Robinson, Isabelle Schmelzer, Carla Saunders, Jytte Selno, Kelly Squires, Nyssa Temmel, Edmund Tobin and Corinne Wilkerson. For project, logistic and organizational help we thank Daniel Ashini, Major John Argue, Peter Armitage, Maureen Baker, Craig Barnes, Kirk Blake, Tim Borlase, Keith Chaulk, Tony Chubbs, Beatrice Decker, Johanne Dussureault, Dr Richard Elliot, Roxanne Hopkins, Major Gary Humphries, Larry Innes, Darlene Jacobs, Kathy Knox, Hans Lindner, Mike Malley, Colonel Paul McCabe, Ben Michel, Ed Oliver, Rob Otto, Donna Paddon, Maurice Pigeon, Joanne Samson, Patricia Squires, Perry Trimper, Bruce Turner, Natasha Voisey and Joe Watson. For statistical advice and study design we are grateful to Dr Anne 
Bowles, Dr Stephen Insley, Tom Jung, Dr Kathy Martin, Dr Michelin Manseau, Dr Greg Robertson, Dr David Schneider, Sean Sharpe and Neil Standon. Geoff Goodyear of Universal Helicopters Ltd, Jim Hudson of Torngat Wilderness Adventures Ltd, Jim Burton of Northeast Sky Aviation and Rick Dawe of Labrador Airways provided major aircraft support. The Institute of Environmental Monitoring and Research, the Canadian Wildlife Service, the Atlantic Cooperative Wildlife Ecology Research Network, the Endangered Species Recovery Fund of World Wildlife Fund Canada, the Dean of Science of Memorial University of Newfoundland, and the Northern Scientific Training Program of the Department of Indian and Northern Affairs Canada funded this work.

\section{References}

Agresti, A. (1996) An Introduction to Categorical Data Analysis. New York, NY, USA: John Wiley and Sons.

Altmann, J. (1974) Observational study of behaviour: sampling methods. Behaviour 49: 227-267.

Anderson, D.E. (1988) Dose-response relationship between human disturbance and brown pelican breeding success. Wildlife Society Bulletin 16: 339-345.

Bowles, A.E., Tabachnick, B. \& Fidell, S. (1991) Review of the effects of aircraft overflights on wildlife: Volume II of III: Technical Report. BBN Systems and Technologies, Canoga Park, CA, Canada.

Brown, A.L. (1990) Measuring the effect of aircraft noise on sea birds. Environment International 16: 587-592.

Brown, A.L. (2001a) Overview of research on the effects of noise on wildlife. Terra Borealis 2: 10-14.

Brown, A.L. (2001b) The response of sea birds to simulated acoustic and visual aircraft stimuli. Terra Borealis 2: 56-59.

Burger, J. (1981) Behavioural responses of Herring Gulls (Larus argentatus) to aircraft noise. Environmental Pollution (Series A) 24: 177-184.

Chesser, R.K., Caldwell, R.S. \& Harvey, M.J. (1976) Effects of noise on feral populations of Mus musculus. Physiological Zoology 48: 323-325.

Davis, M. (1974) Sensitization of the startle response by noise. Fournal of Comparative Physiology and Psychology 87: 571-581.

Delaney, D.K., Grubb, T.G., Beier, P., Pater L.L. \& Reiser, M.H. (1999) Effects of helicopter noise on Mexican Spotted Owls. Fournal of Wildlife Management 63(1): 60-76.

DND (1994) EIS: military flight training - an environmental impact statement on military flying activities in Labrador and Quebec. Unpublished EA. Project Management Office Goose Bay, National Defence Headquarters, Ottawa, Canada.

Dooling, R. (2000) Hearing in birds. In: The Evolutionary Biology of Hearing, ed. D.B. Webster, R.R. Fay \& A.N. Popper, pp. 545-559. New York, NY, USA: Springer-Verlag.

Fidell, S., Barber, D.S. \& Schults, T.J. (1991) Updating a dosageeffect relationship for the prevalence of annoyance due to general transportation noise. Fournal of the Acoustical Society of America 89(1): 221-233.

Fleming, W.J., Dubovsky, J.A. \& Collazo, J.A. (1996) An assessment of the effects of aircraft activities on waterfowl at Piney Island, North Carolina. Unpublished report. North Carolina Cooperative Fish and Wildlife Research Unit, North Carolina, USA.
Goudie, R.I. \& Ankney, C.D. (1986) Body size, activity budgets and diets of sea ducks wintering in Newfoundland. Ecology 67: $1475-1482$.

Goudie, R.I., Brault, S., Conant, B., Kondratyev, A.V., Petersen, M.R. \& Vermeer, K. (1994) The status of sea ducks in north Pacific Rim: toward their conservation and management. Transactions of the North American Wildlife and Natural Resources Conference 59: 27-49.

Green, R.H. (1979) Sampling Design and Statistical Methods for Environmental Biologists. New York, NY, USA: John Wiley and Sons: $257 \mathrm{pp}$.

Grubb, T.G. \& Bowerman, W.W. (1997) Variations in breeding bald eagle response to jets, light planes and helicopters. Fournal of Raptor Research 31: 213-222.

Harrington, F.H. \& Veitch, A.M. (1991) Short-term impacts of lowlevel jet fighter training on caribou in Labrador. Arctic 44: 318327.

Hoffman, H.S. \& Searle, J.L. (1968) Acoustic and temporal factors in the evocation of startle. Fournal of the Acoustical Society of America 43(2): 269-282.

Hunsaker II, D. (2001) The effects of aircraft operations on passerine reproduction. Terra Borealis 2: 41-49.

Jung, T.S. \& Jones, C.C. (2001) Movements and site fidelity of woodland caribou of the Red Wine Mountains Herd in relation to low level aircraft training in Labrador. Terra Borealis 2: 62-63.

Korn, J.H. \& Moyer, K.E. (1966) Habituation of the startle response and of heart rate in the rat. Canadian Fournal of Psychology 20(2): 183-190.

Kosin, I.L. (1958) Effect of simulated airplane sounds on the reproductive functions of the male domestic chicken. Fournal of Applied Physiology 121(2): 217-220.

Larkin, R.P. (1996) Effects of military noise on wildlife: a literature review. US Army Construction Engineering Research Laboratories Technical Report 96/21, Champaign, IL, USA: $74 \mathrm{pp}$.

Larson Davis Laboratories (1997) Model 820 Sound Level Meter user manual. Unpublished document, Larson Davis Inc., Utah, USA.

Maier, J.A., White, R.G., Murphy, S.M. \& Smith, M.D. (2001) Effects of overflights by jet aircraft on activity, movements, habitat and terrain use of caribou. Terra Borealis 2: 60-61.

Moberg, G.P. (1987) A model for assessing the impact of behavioral stress on domestic animals. Fournal of Animal Science 65: 12281235.

Murphy, M., Ritchie, R.J., Palmer, A.G., Nordmeyer, D.L., Roby, D.D. \&. Smith, M.D. (2001) Responses of Peregrine Falcons to military jet aircraft. Terra Borealis 2: 34-36.

Pater, L. (2001) Defining auditory thresholds for animal species. Terra Borealis 2: 22-25.

Pigeon, M.A. (2001) Managing low level jet aircraft noise. Terra Borealis 2: 64-68.

Robertson, G.J. \& Goudie, R.I. (1999) Harlequin duck (Histrionicus histrionicus). The Birds of North America No. 466, series ed. A. Poole \& F. Gill. Philadelphia, PA, USA: The Birds of North America Inc.

Ryals, B.M., Dooling R.J., Westbrook, E., Dent, M.L., MacKenzie, A. \& Larsen, O.N. (1999) Avian differences in susceptibility to noise exposure. Hearing Research 131: 71-88.

SAS Institute Inc. (1993) SAS/STST Software: The GENMOD Procedure, Release 6.09. SAS Technical Report P-243. Cary, NC, USA. 
Selye, H. (1976) Forty years of stress research: principal remaining problems and misconceptions. Canadian Medical Association Fournal 115(1): 53-56.

Squires, K.A. (2003) Pre-incubation behaviour of Harlequin ducks (Histrionicus histrionicus) in Labrador: testing the function of male vigilance and aggression. Masters thesis, Faculty of Forestry, University of British Columbia, Vancouver, BC, Canada: $53 \mathrm{pp}$.

Swennen, C., Leopold, C.M.F. \& de Bruijn, L.L.M. (1989) Timestressed oystercatchers, Haematopus ostralegus, can increase their intake rate. Animal Behaviour 38: 8-22.

Thiessen, G., Shaw, A.A.G., Harris, R.D., Gollop, J.B. \& Webster, H.R. (1957) Acoustic irritation threshold of Peking ducks and other domestic and wild fowl. Fournal of the Acoustical Society of America 29(12): 1301-1306.
Thiessen, G.J. \& Shaw, A.A.G. (1957) Acoustic irritation threshold of ring-billed gulls. Fournal of the Acoustical Society of America 29: 1307-1309.

Trimper, P.G., Standen, N.M., Lye, L.M., Lemon, L., Chubbs, T.E. \& Humphries, G.W. (1998) Effects of low-level jet aircraft noise on the behaviour of nesting osprey. Fournal of Applied Ecology 35: $122-130$.

Trimper, P.G., Knox, K., Shury T., Lye, L. \& Barrow, B. (2003) Response of moulting black ducks to jet activity. Terra Borealis 3: 58-60.

Ward, D.H., Stehn, R.A. \& Derksen, D.V. (2001) Response of geese to aircraft disturbance. Terra Borealis 2: 52-55.

Welch, B.L. \& Welch, A.S. (1970) Physiological Effects of Noise. New York, NY, USA: Plenum Press.

Zar, J. (1999) Biostatistical Analysis. New Jersey, USA: Prentice Hall. 